\title{
Considerations regarding test methods against dust and water ingress protection for Ex equipment
}

\author{
Niculina Vătavu ${ }^{1}$, Mihaela Părăian ${ }^{1}$, Sorin Vătavu ${ }^{2}$, and Mihai Popa ${ }^{1}$ \\ ${ }^{1}$ National Institute of Research and Development for Safety in Mines and Explosion Protection, 32-34 \\ G-ral Vasile Milea, Petroșani, România \\ ${ }^{2}$ University of Petroşani, 20 Universităţii street, Petroşani, 332006, România
}

\begin{abstract}
The explosion danger in all industries where explosive atmospheres generated by the mixture of combustible dusts or flammable gases with air may form, must be treated as a major hazard, as the explosions that may occur can seriously affect both health and safety people, as well as the environment. It is therefore necessary to assess the explosion risk and to establish appropriate measures to reduce it to acceptable levels in accordance with the requirements of the European Directives. An essential element in the assessment of the explosion risk for electrical and non-electrical equipment intended for use in potentially explosive atmospheres is the way in which an appropriate normal degree of protection is provided through the equipment housing (protection against touching of dangerous parts inside the equipment housing and protection against the ingress of dust and water inside it). The aim of the paper is to highlight compliance with the requirements of the ATEX Directive, given that this protection is a basic requirement for explosion protection and to present the important elements to be considered for the assessment of the normal degree of protection and the development of harmonized test methods with the requirements of European standards.
\end{abstract}

\section{Introduction}

In general, a potentially explosive atmosphere can occur in all industries involving flammable or combustible substances (raw materials, intermediate products or finished products and sometimes even waste from production processes).

The explosion danger is mainly related to the formation of potentially explosive atmospheres generated by the mixture of combustible dusts with air and / or flammable gases with air: materials and substances processed, used or released by the technological installation. This danger must be treated as a major danger that can affect both human health and safety and the environment. It is therefore necessary to assess the risk of

\footnotetext{
${ }^{*}$ Corresponding author: niculina.vatavu@insemex.ro
} 
explosion and to establish appropriate measures to reduce it to acceptable levels in accordance with the requirements of European Directives and harmonized standards.

The main purpose of assessing the risk level for a technical installation used in potentially explosive atmospheres is to identify risk factors, quantify the risk level and establish the technical and / or organizational measures required to ensure explosion protection, i.e., conformity assessment of equipment, products / installations with specific requirements. In general, the assessment of the products conformity with the specified requirements is an activity that may be performed by a first, second or third party and may be regulated or unregulated by specific rules and standards.

In the field of explosion protection there are two European Directives: Directive 2014/34 / EU, taken over in national legislation by GD 245/2016 which regulates the placing on the European market of products intended for use in potentially explosive atmospheres and Directive 1999/92 / EC, taken over national legislation by GD 1058/2006 which regulates their safe use.

\section{Compliance requirements for Ex equipment to reduce the risks posed by potentially explosive atmospheres}

According to Directive 2014/34 / EU, technical equipment intended for use in potentially explosive atmospheres is divided into two groups (group I: mining and group II: gases, vapours, mists, flammable liquids and combustible dusts) and three categories: 3G / 3D, 2G / 2D, 1G / 1D depending on the level of protection required for safe use in the area to be used [1], [2]. According to harmonized standards, technical equipment intended for use in potentially explosive atmospheres is divided into three groups (group I: mining, group II: gases, vapours, mists, flammable liquids and group III: combustible dusts) and three categories depending on the required level of protection: $\mathrm{Gc} / \mathrm{Dc}, \mathrm{Gb} / \mathrm{Db}, \mathrm{Ga} / \mathrm{Da}$.

Table 1. The protection level required depending on the explosive atmosphere

\begin{tabular}{|c|c|c|c|c|c|c|c|}
\hline ZONE & $\begin{array}{l}\text { Presence of } \\
\text { an explosive } \\
\text { atmosphere } \\
\end{array}$ & $\begin{array}{c}\text { Ignition } \\
\text { sources } \\
\text { avoidance } \\
\end{array}$ & $\begin{array}{l}\text { Level of } \\
\text { protection } \\
\text { required }\end{array}$ & $\begin{array}{l}\text { Group II } \\
\text { category }\end{array}$ & EPL & $\begin{array}{l}\text { Group II } \\
\text { category }\end{array}$ & EPL \\
\hline 2 or 22 & $\begin{array}{c}\text { Infrequent or } \\
\text { only on a } \\
\text { short period } \\
\text { of time }\end{array}$ & $\begin{array}{c}\text { During } \\
\text { normal } \\
\text { operation }\end{array}$ & NORMAL & $3 \mathrm{G}$ & Gc & $3 \mathrm{D}$ & Dc \\
\hline 1 or 21 & $\begin{array}{l}\text { Likely to } \\
\text { occur }\end{array}$ & $\begin{array}{l}\text { Also during } \\
\text { foreseeable } \\
\text { malfunctions } \\
\text { (one defect) }\end{array}$ & HIGH & $2 \mathrm{G}$ & $\mathrm{Gb}$ & $2 \mathrm{D}$ & $\mathrm{Db}$ \\
\hline 0 or 20 & $\begin{array}{l}\text { Continuously, } \\
\text { for long } \\
\text { periods of } \\
\text { time or } \\
\text { frequently }\end{array}$ & $\begin{array}{l}\text { Also during } \\
\text { rare } \\
\text { malfunctions } \\
\text { (two defects } \\
\text { independent) }\end{array}$ & $\begin{array}{l}\text { VERY } \\
\text { HIGH }\end{array}$ & $1 \mathrm{G}$ & $\mathrm{Ga}$ & $1 \mathrm{D}$ & $\mathrm{Da}$ \\
\hline \multicolumn{2}{|c|}{$\begin{array}{c}\text { USERS } \\
\text { Directive1999/92/EC } \\
\text { (HG 1058/2006) }\end{array}$} & \multicolumn{6}{|c|}{$\begin{array}{c}\text { MANUFACTURERS } \\
\text { European Directive 2014/34/UE } \\
\text { (HG 245/2016) }\end{array}$} \\
\hline
\end{tabular}

Table 1 shows schematically the relationship between the hazardous atmosphere area and the protection level required for the equipment, so as to avoid initiation sources during normal operation, during foreseeable failures or rare failures. In general, if possible, equipment should be located in unclassified areas Ex and if this is not possible, it should be located in the least dangerous area. 
Their choice and installation must take into account the three basic principles of explosion prevention and explosion protection [3], [4]:

a) explosive atmospheres prevention by avoiding them;

b) avoid all effective ignition sources;

c) protection regarding the effects limitation of explosions to an acceptable limit by constructive protection measures.

In order to ensure adequate safety in potentially explosive atmospheric spaces, various explosion protection techniques may be applied to equipment or parts thereof. Preventive measures may be used to reduce the risk of simultaneous ignition and explosive atmospheres in the hazardous area. The issue can be addressed in one of the following ways:

a) suppression or avoidance of dangerous conditions;

b) explosion-proof electrical equipment use;

c) applied control conditions that reduce the simultaneous occurrence of an explosive atmosphere and a source of ignition.

Therefore, in order to reduce the explosions risk in industrial spaces with potentially explosive atmospheres, special construction equipment must be used that does not produce electric sparks, electric springs, mechanical sparks (impact and friction), static electricity, overheated surfaces, or other energy sources that could initiate an explosion. Another requirement for equipment intended for potentially explosive atmospheres is to ensure a normal degree of protection against the ingress of dust and water into the equipment housing.

\section{Ensuring the Ex equipment protection by preventing water and dust from entering the housings}

In Ex hazardous areas, equipment certified according to the intended destination must be used, which in addition to the protection measures imposed (type of explosion protection, temperature class and explosion group of liquids, explosive gases, mists and / or dust suspensions in air or in the form layer), must be protected by enclosures to ensure:

- Persons protection against access to dangerous parts inside the housing;

- The equipment protection of inside the housing against the ingress of foreign solids;

- The equipment protection inside the housing against harmful effects due to water ingress.

Ensuring a certain normal degree of protection against the penetration of dust and water into the equipment housing is symbolized by the international protection code - IP code, sometimes called penetration protection code, according to SR EN 60529 and is definitive as a coding system for indicate the protection provided by a housing and additional information about these protections.

Table 2. Symbolization of IP codes (international protection)

\begin{tabular}{|c|c|c|c|c|c|}
\hline Letters cod & $\begin{array}{c}\text { The first } \\
\text { characteristic } \\
\text { figure: } \\
\text { protection } \\
\text { against solid } \\
\text { particles }\end{array}$ & $\begin{array}{c}\text { The second } \\
\text { characteristic } \\
\text { figure: } \\
\text { protection } \\
\text { against liquid } \\
\text { penetration }\end{array}$ & $\begin{array}{c}\text { Third digit: } \\
\text { mechanical } \\
\text { impact } \\
\text { resistance }\end{array}$ & $\begin{array}{c}\text { Additional } \\
\text { letter: } \\
\text { Other } \\
\text { protections }\end{array}$ & $\begin{array}{c}\text { Additional } \\
\text { letter: } \\
\text { Other } \\
\text { protections }\end{array}$ \\
\hline $\begin{array}{c}\text { IP (international } \\
\text { protection) }\end{array}$ & $\begin{array}{c}0 \div 6 \text { or the } \\
\text { letter X }\end{array}$ & $\begin{array}{c}0 \div 9 \text { or the } \\
\text { letter X }\end{array}$ & $0 \div 9$ & $\mathrm{~A}, \mathrm{~B}, \mathrm{C}, \mathrm{D}$ & $\mathrm{F}, \mathrm{H}, \mathrm{M}$, \\
$\mathrm{S}, \mathrm{W}$
\end{tabular}


Additional letter that are added represent the personnel protection against the access to dangerous parts with: $\mathrm{A}$ - the back of the hand, B - finger, C - instrument (tool), D - wire.

Additional letters that are added represent the equipment protection: $\mathrm{F}$ - oil resistance, $\mathrm{H}$ - high voltage equipment, $\mathrm{M}$ - resistance to running in water during diving, $\mathrm{S}$ - resistance to immersion in water without operation, $\mathrm{W}$ - resistance to extreme weather conditions.

Table 3. The elements of the IP code and their meanings

\begin{tabular}{|c|c|c|c|c|}
\hline \multicolumn{2}{|r|}{ First characteristic numeral } & \multicolumn{2}{|c|}{ Second characteristic numeral } & \multirow{2}{*}{$\begin{array}{c}\begin{array}{c}\text { Protection } \\
\text { against } \\
\text { mechanical } \\
\text { impacts }\end{array} \\
\text { IK } \\
\end{array}$} \\
\hline IP & Description & IP & Description & \\
\hline 0 & Unprotected & 0 & Unprotected & IK 00 \\
\hline 1 & $\begin{array}{l}\text { Protected against foreign solids } \\
\text { with a diameter of } 50 \mathrm{~mm} \text { and } \\
\text { above (protected against hand-to- } \\
\text { hand access to dangerous parts) }\end{array}$ & 1 & $\begin{array}{l}\text { Protected against drops of } \\
\text { water falling vertically }\end{array}$ & $\begin{array}{l}\text { IK 01, impact } \\
\text { energy } 0.14 \mathrm{~J}\end{array}$ \\
\hline 2 & $\begin{array}{l}\text { Protected against foreign solids } \\
\text { with a diameter of } 12 \mathrm{~mm} \text { and } \\
\text { larger (protected against finger } \\
\text { contact to dangerous parts) }\end{array}$ & 2 & $\begin{array}{c}\text { Protected against vertical } \\
\text { droplets of water that can be } \\
\text { rotated at } 15^{\circ}\end{array}$ & $\begin{array}{l}\text { IK 02, impact } \\
\text { energy } 0.2 \mathrm{~J}\end{array}$ \\
\hline 3 & $\begin{array}{l}\text { Protected against foreign solids } \\
\text { with a diameter of } 2.5 \mathrm{~mm} \text { and } \\
\text { higher (fine tools, wires) }\end{array}$ & 3 & $\begin{array}{l}\text { Protected against sprayed } \\
\text { water at an angle of up to } 60^{\circ} \\
\text { to the vertical }\end{array}$ & $\begin{array}{l}\text { IK 03, impact } \\
\text { energy } 0.35 \mathrm{~J}\end{array}$ \\
\hline \multirow{2}{*}{4} & \multirow{2}{*}{$\begin{array}{l}\text { Protected against foreign solids } \\
\text { with a diameter of } 1 \mathrm{~mm} \text { and higher } \\
\text { (fine tools, wires) }\end{array}$} & 4 & $\begin{array}{l}\text { Protected against sprayed } \\
\text { water on all sides }\end{array}$ & $\begin{array}{l}\text { IK 04, impact } \\
\text { energy } 0.5 \mathrm{~J}\end{array}$ \\
\hline & & 5 & $\begin{array}{c}\text { Protected against water jets } \\
\text { on all sides }\end{array}$ & $\begin{array}{l}\text { IK 05, impact } \\
\text { energy } 0.7 \mathrm{~J}\end{array}$ \\
\hline 5 & $\begin{array}{l}\text { Protected against dust (against } \\
\text { hazardous deposits) }\end{array}$ & 6 & $\begin{array}{l}\text { Strong water jet, equivalent to } \\
\text { sea waves during storm }\end{array}$ & $\begin{array}{l}\text { IK 06, impact } \\
\text { energy } 1 \mathrm{~J}\end{array}$ \\
\hline \multirow{4}{*}{6} & \multirow{4}{*}{ Dust-tight } & 7 & $\begin{array}{c}\text { Protected against immersion } \\
\text { in water }\end{array}$ & $\begin{array}{c}\text { IK 07, impact } \\
\text { energy } 2 \mathrm{~J}\end{array}$ \\
\hline & & 8 & $\begin{array}{l}\text { Protected during permanent } \\
\text { immersion in water- } 1000 \mathrm{~mm}\end{array}$ & $\begin{array}{c}\text { IK 08, impact } \\
\text { energy } 5 \mathrm{~J}\end{array}$ \\
\hline & & 9 & $\begin{array}{c}\text { Protected against strong water } \\
\text { jets (high pressure and high } \\
\text { temperature), associated with } \\
\text { steam washing }\end{array}$ & $\begin{array}{c}\text { IK 09, impact } \\
\text { energy } 10 \mathrm{~J}\end{array}$ \\
\hline & & & & $\begin{array}{l}\text { IK 10, impact } \\
\text { energy } 20 \mathrm{~J}\end{array}$ \\
\hline
\end{tabular}

If one of the 2 characteristic figures does not need to be determined, it shall be replaced by the letter $X$. In the case of protection against dust entering the housing, the upper figures shall cover the lower figures and in the case of protection against water penetration inside the housing it shall be noted that a housing designated with the normal degree of protection IP X7 or IP X8 is unsuitable for IP X5 or IP X6. Also, an IP X9 housing is unsuitable for IP X7, IPX8, IP X6, IP X5, unless it has multiple operating conditions, as shown in Table 4. 
Table 4. Marking the second characteristic digit for multiple uses

\begin{tabular}{|c|c|c|c|}
\hline $\begin{array}{c}\text { Housing } \\
\text { corresponding } \\
\text { to water jets } \\
\text { (second } \\
\text { characteristic } \\
\text { figure) }\end{array}$ & $\begin{array}{c}\text { Temporary or } \\
\text { prolonged } \\
\text { immersion } \\
\text { (second } \\
\text { characteristic } \\
\text { digit) }\end{array}$ & Marking & $\begin{array}{c}\text { Application } \\
\text { field }\end{array}$ \\
\hline 5 & 7 & IP X5 / IP X7 & Multiple \\
\hline 5 & 8 & IP X5 / IP X8 & Multiple \\
\hline 6 & 7 & IP X6 / IP X7 & Multiple \\
\hline 6 & 8 & IP X6 / IP X8 & Multiple \\
\hline 9 & 7 & IP X7 / IP X9 & Multiple \\
\hline 9 & 8 & IP X8 / IP X9 & Multiple \\
\hline 5 and 9 & 7 & IP X5 / IP X7 / IP X9 & Multiple \\
\hline 5 and 9 & 8 & IP X5 / IP X8 / IP X9 & Multiple \\
\hline 6 and 9 & 7 & IP X6 / IP X7 / IP X9 & Multiple \\
\hline 6 and 9 & 8 & IP X6 / IP X8 / IP X9 & Multiple \\
\hline- & 7 & IP X7 & Limited \\
\hline- & 8 & IP X8 & Limited \\
\hline 9 & - & IP X9 & Limited \\
\hline 5 and 9 & - & IP X5 / IP X9 & Multiple \\
\hline 6 and 9 & - & IP X6 / IP X9 & Multiple \\
\hline & & & \\
\hline
\end{tabular}

\section{Test methods development of for determining the normal degree of protection of equipment Ex}

To assess the conformity of Ex equipment with the requirements of the ATEX Directive 2014/34 / EU, transposed into Romanian legislation by GD 245/2016, as established in the harmonized standards under the ATEX Directive, the certification body INSEMEX-OEC, RENAR accredited body (Certificate of accreditation ON 046) and notified in Brussels with NB No 1809 must carry out evaluations based on the type tests results carried out in competent laboratories.

INSEMEX GLI test laboratory group belonging to INSEMEX Petrosani, the main supplier of laboratory testing services for the product certification body. The laboratory is accredited by RENAR - Romanian Accreditation Association (accreditation certificate no. LI 347) regarding the competence to perform specific tests based on the requirements of SR ISO / IEC 17025: 2018 and the accreditation criteria established by RENAR - National Accreditation Body of test and testing laboratories.

In this regard, in order to assess the Ex-equipment conformity with the requirements of the applicable harmonized standards, to test the determination of the normal degree of protection, within INSEMEX GLI Testing Laboratories Group, after analysing the required technical solutions, state-of-the-art test stands were purchased and several tests have been carried out to protect against the ingress of dust or water into the equipment housing. It was also reviewed, validated and implemented in the Quality system of the accredited laboratory the water and dust test procedure for each characteristic digit of the IP code XX, registered procedure "PI 55 - DETERMINATION OF THE NORMAL DEGREE OF IP PROTECTION (both digits)" which can be applied to both normal and large equipment [5]. 


\subsection{Tests to determine the total or partial protection against the ingress of dust into the housing of the Ex-equipment}

In Figure 1a and Figure $1 \mathrm{~b}$ is presented the Dust Chamber (with a volume of $0.6 \mathrm{~m}^{3}$ ) used for testing equipment with normal dimensions, and in Figure $2 \mathrm{a} \div 2 \mathrm{c}$ is presented the large dust chamber. This dust test chamber can be used for testing large equipment up to $2000 \mathrm{~kg}$ which can be category 1 and 2, in accordance with the requirements of SR EN 60529.

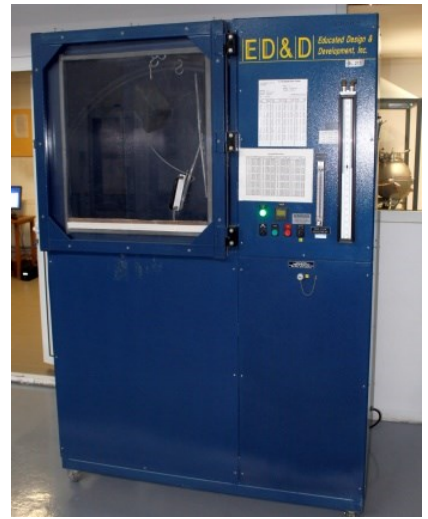

Fig. 1a. - The dust chamber

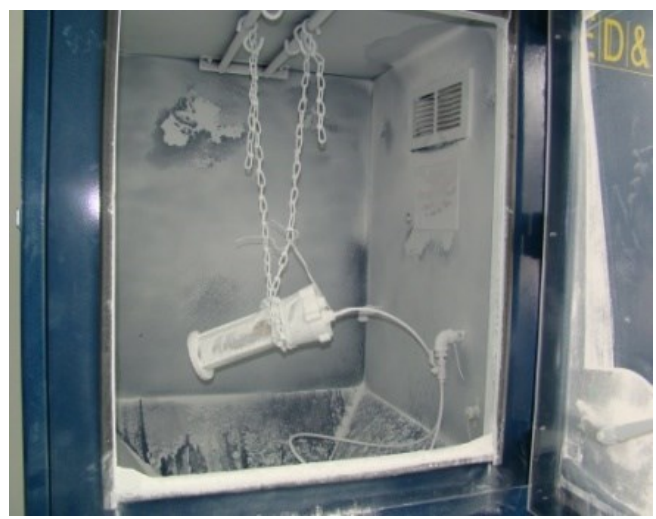

Fig. 1b. - Dust tested equipment

For testing dust category 1 equipment (IP $5 \mathrm{X}$ or IP $6 \mathrm{X}$ ) the requirements are to extract 80 free internal air volumes from the tested equipment, but not to exceed an hourly extraction flow of 60 times the housing volume and depression must not exceed $2 \mathrm{kPa}$ [6].

To achieve these conditions, specialized software is used, which controls the test parameters as follows:

- limiting the extraction pressure to $200 \mathrm{~mm}$ water column;

- entering the extraction flow value according to the performed calculation and the automatic flow control.

The extraction flow is controlled by a PLC with frequency converter for the supply voltage of the vacuum pump motor and flow and pressure sensors. The sensors supply signal to the computer and the related software, the latter sending a PID signal to the PLC.

The software also performs the logger function, recording the values of flow, pressure, temperature and time for the test performed, the data can be used to draw the test diagram.

The entire camera system is fully automated, the performance of the test depending only on the test time introduction in the software. After pressing the START button, the software performs the test autonomously and turns off the camera at the end of the test.

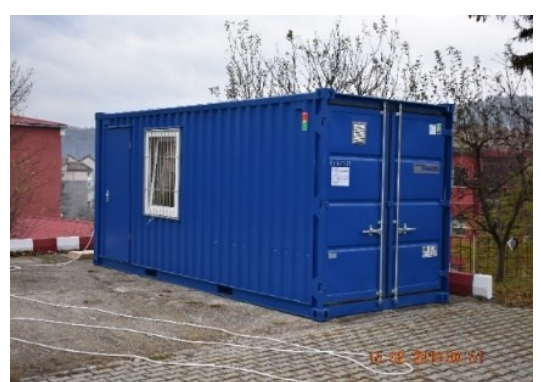

Fig. 2a. - Large dust chamber

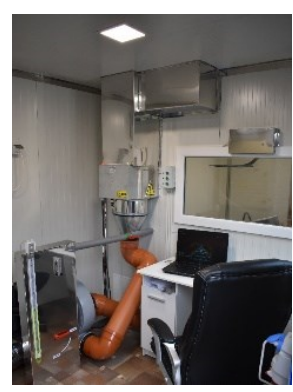

Fig. 2b. - The control room

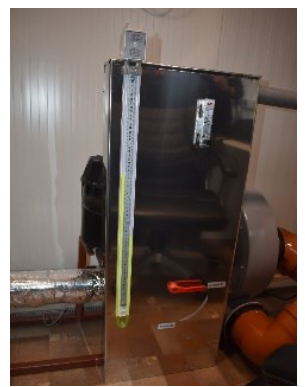

Fig. 2c. - Control panel 
Figure 3 shows the tracked parameters graph with real-time recordings, monitored using control software, acquisition, processing and data recording.

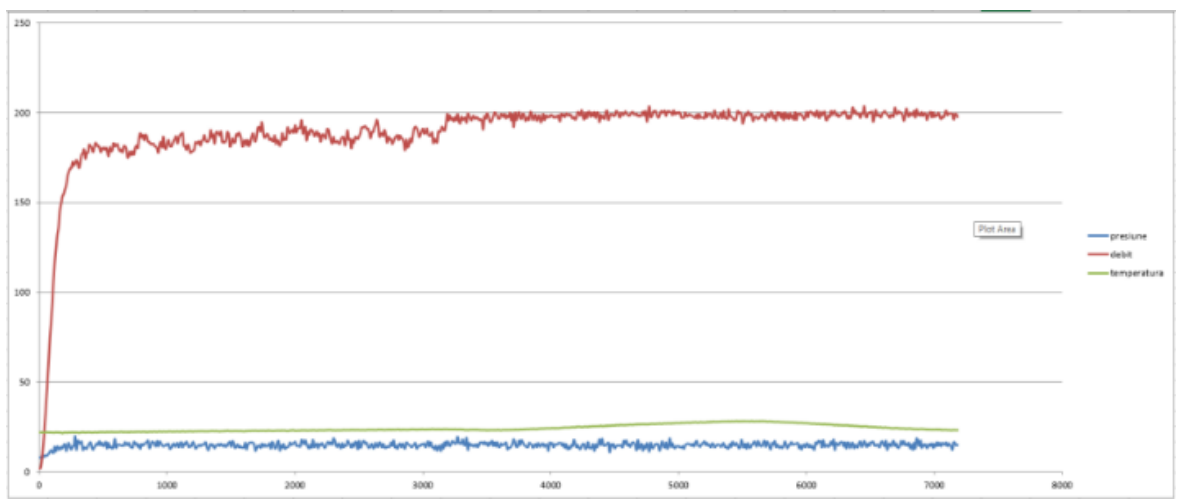

Fig. 3. Time variation of pressure, flow and temperature

\subsection{Tests to determine protection against the ingress of water into the housing of the equipment}

Figure 4 shows the test stand for water falling in the form of rain - IP X3 and protection against water splashes - IP X4.

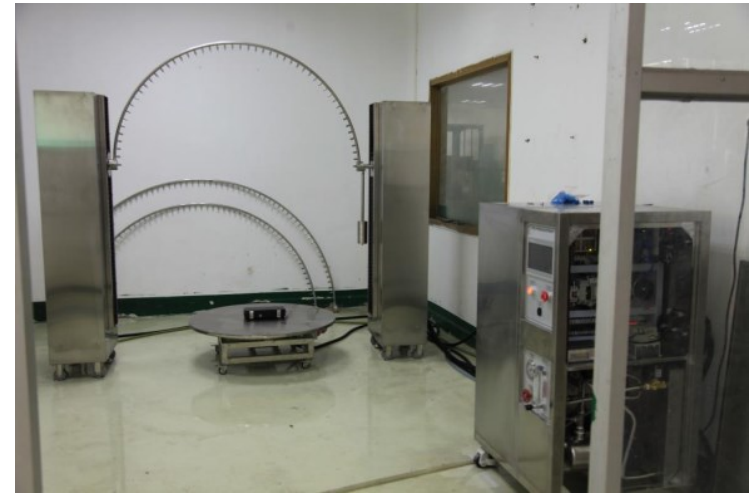

Fig. 4. Test stand for protection against water in the form of rain or water splashes

The test stand shown is used to test electrical and non-electrical equipment in order to determine the second characteristic figure IP X3 (protection against water falling in the form of rain) and IP X4 (protection against water splashes).

The test stand is fully automated, with all adjustable parameters: height $500 \div 1250$ $[\mathrm{mm}]$, oscillating spring speed, pressure and flow, test duration, rotating table for the tested equipment.

According to the standard SR EN 60529, depending on the protection imposed on the water (IP X3 or IP X4) and the radius of the oscillating tube in table 5 are given values established for the total flow and the number of nozzles. 
Table 5. Flow ratio - number of nozzles

\begin{tabular}{|c|c|c|c|c|c|c|}
\hline \multirow{2}{*}{$\begin{array}{c}\text { Radius of } \\
\text { oscillating } \\
\text { spring }[\mathrm{mm}]\end{array}$} & \multicolumn{3}{|c|}{$\begin{array}{c}\text { IP X3 } \\
\text { number of }\end{array}$} & \multicolumn{2}{|c|}{ Flow instead } & \multicolumn{3}{|c|}{ IP X4 } \\
\cline { 3 - 4 } \cline { 6 - 7 } & nozzles & L/min & L/h & nozzles & Flow instead \\
\hline 200 & 8 & 0.56 & 33.6 & 12 & 0.84 & 50.4 \\
\hline 400 & 16 & 1.1 & 66 & 25 & 1.8 & 108 \\
\hline 600 & 25 & 1.8 & 108 & 37 & 2.6 & 156 \\
\hline $\mathbf{8 0 0}$ & $\mathbf{3 3}$ & $\mathbf{2 . 3}$ & $\mathbf{1 3 8}$ & $\mathbf{5 0}$ & $\mathbf{3 . 5}$ & $\mathbf{2 1 0}$ \\
\hline $\mathbf{1 0 0 0}$ & $\mathbf{4 1}$ & $\mathbf{2 . 9}$ & $\mathbf{1 7 4}$ & $\mathbf{6 2}$ & $\mathbf{4 . 3}$ & $\mathbf{2 5 8}$ \\
\hline $\mathbf{1 2 0 0}$ & $\mathbf{5 0}$ & $\mathbf{3 . 5}$ & $\mathbf{2 1 0}$ & $\mathbf{7 5}$ & $\mathbf{5 . 3}$ & $\mathbf{3 1 8}$ \\
\hline 1400 & 58 & 4.1 & 246 & 87 & 6.1 & 366 \\
\hline 1600 & 67 & 4.7 & 282 & 100 & 7.0 & 420 \\
\hline
\end{tabular}

Under the same performance conditions, for large equipment that cannot be tested with the oscillating tube stand, use the portable sprayer shown in Figure 5a, powered by the water tank shown in Figure 5b.

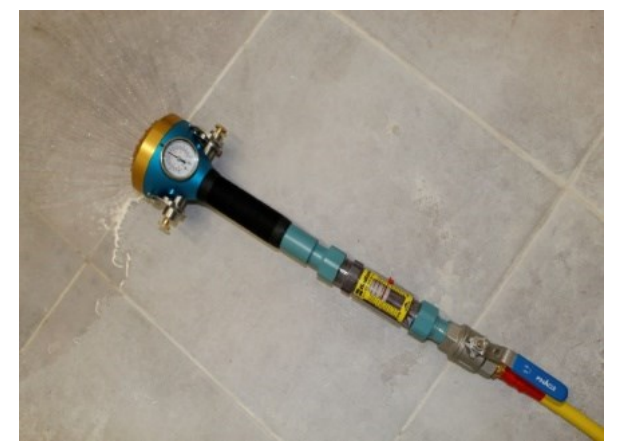

Fig. 5a. - Portable sprayer

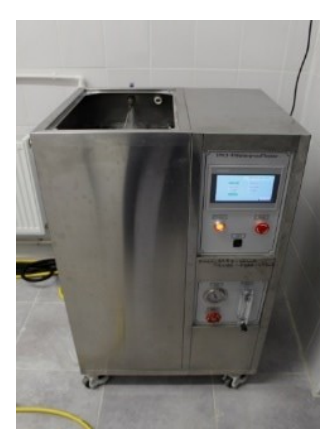

Fig. 5b. - Water tank

According to ISO 17025, it is required that testing laboratories have a monitoring procedure to validate the tests results and calibrations performed. In general, this monitoring is planned and may include participation in interlaboratory comparisons or proficiency testing programs.

Interlaboratory comparisons represent the organization, performance and evaluation of measurements or tests on the same product (equipment) or the like by at least two or more laboratories in accordance with preestablished conditions.

In this regard, to ensure the quality of the tests, the INSEMEX GLI Test Laboratories Group successfully participated in a round of laboratory comparisons organized by PTB Germany, which was attended by 84 accredited laboratories from several countries.

The results obtained in the interlaboratory tests for the determination of IP5X are shown in Figure 6 and for the determination of IPX4 in Figure 7. The results obtained by the test laboratory within INSEMEX GLI are highlighted in yellow (LC0026). 


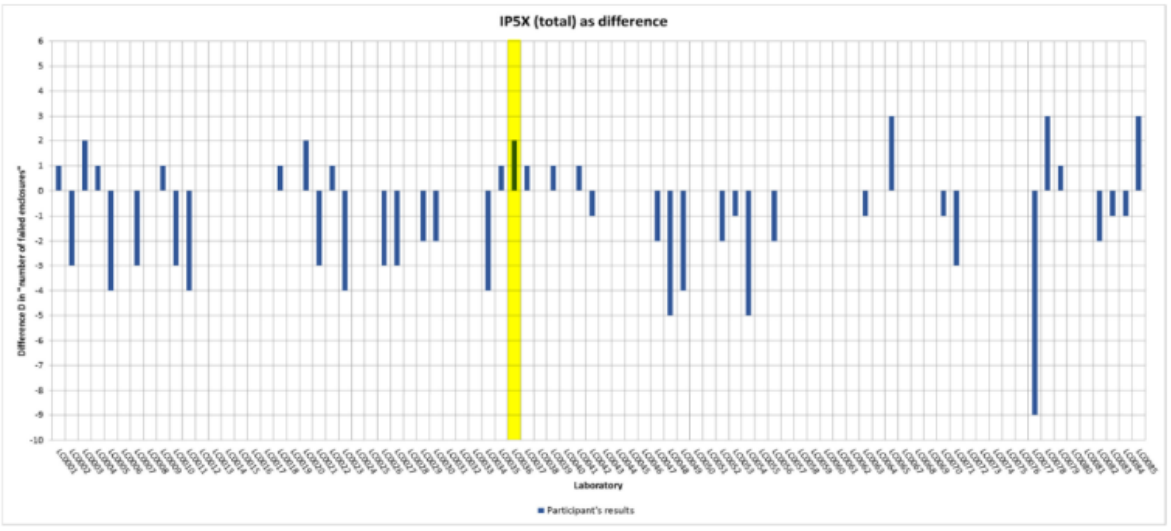

Fig. 6. Results (as difference) for IP 5X. INSEMEX GLI laboratory at position LC0026 [8]

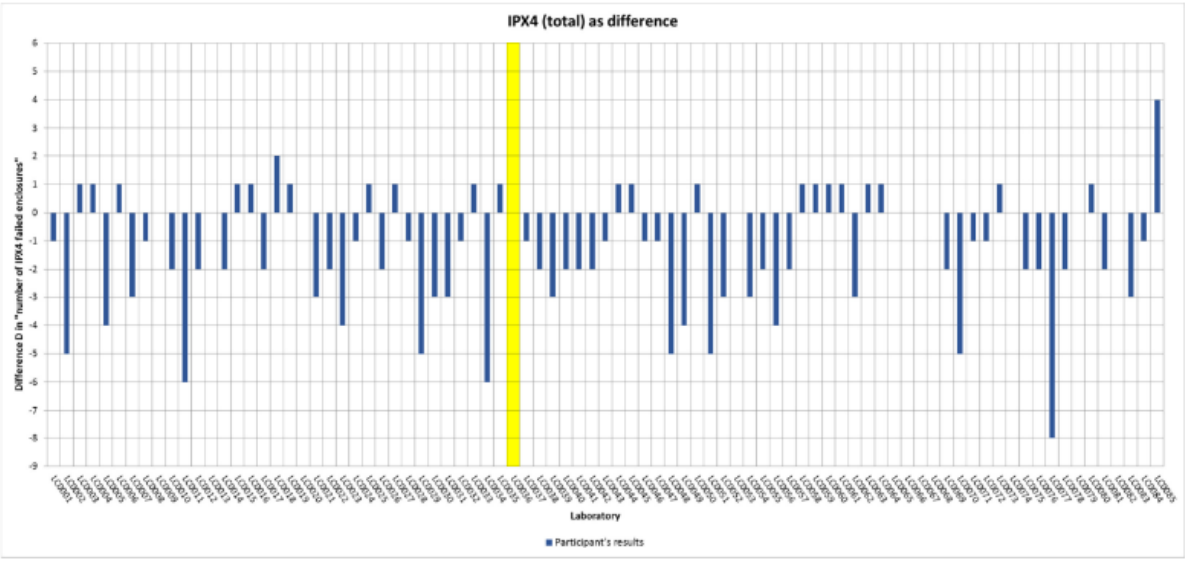

Fig. 7. Results (as difference) for IP X4. INSEMEX GLI laboratory at position LC0026 [8]

The two graphs analysis shows that, after evaluating the results obtained in the interlaboratory tests between the 84 participating test laboratories, there are 14 laboratories with a warning signal and 3 laboratories that are outside the allowed limits. The results obtained by the GLI - INCD INSEMEX laboratory are very good.

\section{Conclusions}

In accordance with the ATEX Directive requirements, all Ex-equipment must comply with the essential safety requirements for ensuring the normal degree of protection (IP code), i.e., protection against access to dangerous parts inside the equipment, protection against the penetration of foreign solids and protection against water penetration inside the housings.

Given the dynamics of the European standards development, it is necessary to continuously develop specific test and testing methods for electrical and non-electrical equipment.

In this regard, in order to assess the Ex-equipment conformity with the applicable harmonized standards requirements, respectively the test for determining the normal degree of protection IP XX, within INSEMEX GLI Testing Laboratories Group, after analysing the required technical solutions, state-of-the-art test stands were purchased. several specific tests were performed. 
The paper presents two modern test stands, used to determine the partial or total protection against dust penetration inside the equipment, equipped with automated systems for achieving the planned test parameters and specialized software for recording values for drawing test diagrams.

To test against water ingress, in order to determine the second characteristic figure IP $\mathrm{X} 3$ (protection against water falling in the form of rain) and IP X4 (protection against water splashes), two fully automated stands are presented, equipped with software parameter adjustment and recording.

Following the tests performed, the water and dust test procedure was reviewed, validated and implemented in the Quality system of the accredited laboratory for each characteristic figure in the IP XX code, respecting all the requirements of the ISO 17025 standard.

Also to ensure the quality of the tests, the INSEMEX GLI Test Laboratory Group successfully participated in a round of non-laboratory comparisons organized by PTB Germany in which 84 accredited test laboratories from several countries participated.

\section{References}

1. N. Vătavu, E. Ghicioi, S. Vătavu, M. Părăian, A. Jurca, F. Păun, D. Gabor, M. Popa Research on the identification of the dangers of dust and water entering equipment for potentially explosive atmospheres, Universitaria SIMPRO, Conference Procedings, Petroșani, 409-415, (2018)

2. N. Vătavu, A. Jurca, S. Vătavu, and D. Gabor, Research on the improvement of test methods for the determination of dust penetration in enclosures of equipment intended for explosive atmospheres, 9th International Symposium on Occupational Health and Safety SESAM (2019)

3. N. Vătavu ș.a., Cerințe de securitate pentru echipamentele protejate ptin carcase " $t "$ utilizate in spații industriale cu pericol de praf combustibil, Editura INSEMEX, ISBN 978-606-876109-1, (2018)

4. $* * *$ ATEX 2014/34/EU Guidelines: Guidelines on the Application of Council Directive 2014/34/UE OF THE EUROPEAN PARLIAMENT AND OF THE COUNCIL of 26 February 2014 on the harmonization of the laws of the Member States relating to equipment and protective systems intended for use in potentially explosive atmospheres, 2nd EDITION - Dec 2017

5. PNCDI - NUCLEU cod: PN 18170201 - Cercetări pentru dezvoltarea capacității de evaluare, testare a echipamentului tehnic destinat utilizării în spații cu risc de explozie și a echipamentului de protecție

6. SR EN 60529 (1995) + SR EN 60529:1995/A1(2003) + SR EN 60529:1995/A2 (2015) + SR EN 60529:1995/AC (2017), Grade de protecţie asigurate prin carcase (Cod IP)

7. SR EN ISO / IEC 17025:2018, Cerințe generale pentru competența laboratoarelor de încercări și etalonări (2018)

8. Lisa Ostermann, Interim Report for the program "Tests of Enclosures - Test Round 2019" of the PTB Ex Proficiency Testing Scheme (2020)

9. PTB Working Group 3.54, Roll-out for Test Round 2021, (2021)

10. Martin Thedens, PTB Workshops 2020 presentation, (2020)

11. Detlev Markus, PTB Workshops 2020 presentation, (2020)

12. Lisa Ostermann, PTB Workshops 2020 presentation, (2020) 